\title{
Youth Entrepreneurship in Agriculture and Rural Development: Nigeria
}

\section{Suresh Babu and Yuan Zhou}

Young people engaging in agricultural entrepreneurship in developing countries face several challenges. Above all, they lack adequate access to important resources and opportunities. These include land, credit, farm inputs, agronomic and vocational training, insurance, and lucrative markets.

Addressing these challenges requires answers to some key questions: Which factors drive the success of youth entrepreneurs in developing countries? What type of business 'ecosystem' is best suited for their development? What roles should the various stakeholders play in making youth entrepreneurship flourish nationally? How can young people expand their start-ups to become small, medium, or largescale businesses?

To answer these questions, the International Food Policy and Research Institute (IFPRI) and the Syngenta Foundation for Sustainable Agriculture (SFSA) developed a conceptual framework. This framework classifies contextual and driving factors that contribute to the success of youth entrepreneurship. There are four broad categories for intervention: policy, institutional, technological, and individual capabilities. The figures below display the framework and related contextual and driving factors. 


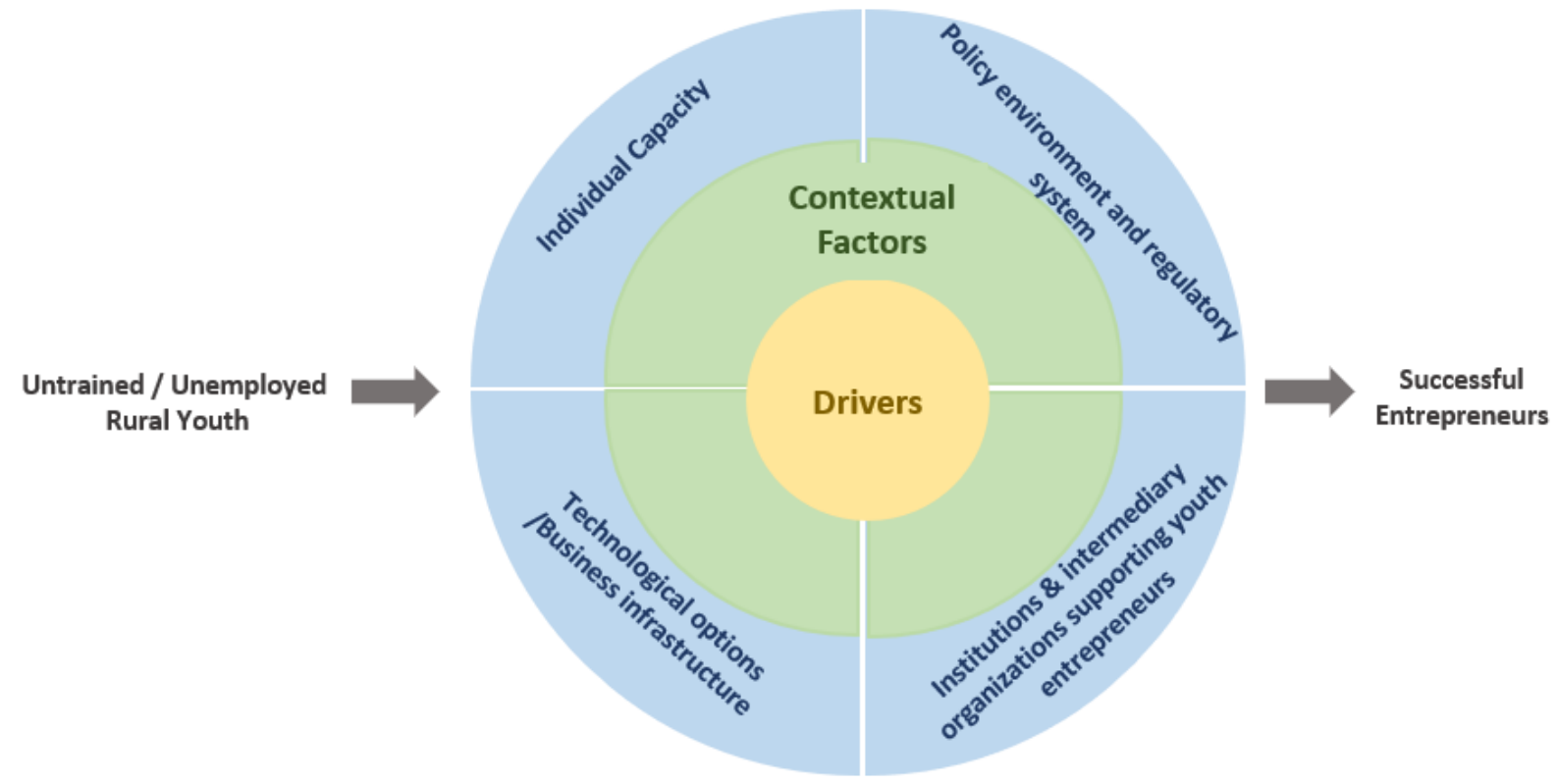

Source: Authors' compilation

Table 1: Selected key factors and drivers for rural youth empowerment through entrepreneurship

$\begin{array}{lll}\text { Strategic Areas } & \text { Contextual Factors } & \text { Drivers }\end{array}$

Policy environment and regulatory system Political environment development for youth / youth migration

Public-Private Partnership opportunities Infrastructure for business / access to assets (such as land, markets, etc.)

Governance and judicial system

Sound financial system

Regulatory environment

Institutions and intermediary organizations supporting youth entrepreneurs
Enabling business environment / financial services

Existence of Chambers of Commerce Existence of technical institutions / skill development institutions / building youth capacity Existence of youth associations - networks and mentorships institutions Development of institutional partnerships in value chains-

Telecommunication infrastructure / ICT and its adoption

Availability of technology and innovation Value chain development opportunities / agribusiness incubators / academic / research linkage

Information and knowledge system supporting youth
National youth policies / Social investment / youth development fund Harmonized policy system including an established entrepreneurship ecosystem Agribusiness strategies / policies (across agribusiness value chains)

Export / market / trade opportunities Access to credit and insurance Regulatory support

Multi-stakeholder approaches to youth and market opportunities

Access to finance and credit

Access to knowledge and skill development Support from Chambers of Commerce for youth development

Farmer organizations, etc. encouraging youth development

Agribusinesses courses available at technical institutions or post-secondary level

Connectivity / access to internet / Cost of mobile / data

Access to new technology and its adoption by youth

Youth are guided by an entrepreneur ecosystem with multi-stakeholder participation Access to relevant and reliable information 
Rural roads, storage/logistics infrastructure

Working / family business experience

Professional incubator facilities for the youth

Access to knowledge and research

Mentorship in business, networking and com-

munity support-
Access to input and output markets / processing and storage facilities

Incentives and motivations

Education / aptitude for learning

Ability / soft skills exposure

Business attitude and professional outlook and skills

Source: Authors' compilation

Using this conceptual framework, we ran studies on youth agribusiness entrepreneurship in Nigeria, India, and Bangladesh. The studies included interviews with young entrepreneurs in the sector. Selection was based on advice from national youth entrepreneurship units and program managers. Other considerations included age, accessibility, and years in business. We used a pre-tested questionnaire in a combination of face-to-face interviews, field visits and online conversations. Our aim was to collect and analyze information leading to policy and program recommendations. This Policy Brief summarizes findings from Nigeria ${ }^{1}$.

We selected seven youth entrepreneurs for the study here. Four focus on rural agribusinesses; the others are urban tech entrepreneurs aiming to connect farmers and aggregators better with markets and consumers. Some have links to research and innovation systems and had been able to upgrade their businesses in line with sector standards. However, none of them are fully integrated into larger supportive environments or a multi-stakeholder initiative on youth entrepreneurship. They have businesses of different sizes, established at different speeds. Education up to undergraduate level seems to help accelerate business establishment and ultimate success. Vocational training for technical and business skill development nonetheless remains a necessary first step towards youth entrepreneurship. Scaling up then requires mentorship, with suitable incentives for the mentors.

In Nigeria, the government, private sector, NGOs, and donor community all support entrepreneurship in agriculture. Several policies and strategies already facilitate the promotion of youth employment and entrepreneurship. Policy documents identify youth entrepreneurship development as a key strategy for agriculture and rural transformation. However, systematic translation of these strategies into investment and coordinated action remains limited. Entrepreneurship programs lack a systematic approach, operate in isolation, remain project-driven, involve few stakeholders, and are poorly linked to other elements of a business ecosystem. Interventions have so far concentrated on training youth for employment rather than helping entrepreneurs to create jobs. Existing agribusiness can hire only a limited number of young people. There is a strong need to develop further enterprises that can absorb more youth.

Rural Nigeria offers a range of opportunities. Young entrepreneurs can, for example, engage directly with farmers and farmer organizations as service providers. They can operate in specific segments of agricultural commodity chains. There are also opportunities to serve specific needs of large companies. Alternatively, entrepreneurs can start their own production and processing businesses, supported by an incubator or other development facility.

However, several key challenges remain apparent at the policy, institutional, technology and infrastructure and individual levels. Further broad efforts are required to improve access to infrastructure and

\footnotetext{
${ }^{1}$ The full report on Nigeria will be out in October 2020.
} 
technology, credit and insurance, and affordable education and training. The regulatory system for agricultural product quality also needs strengthening.

\section{ABOUT THE AUTHORS}

- Suresh Babu, Senior Research Fellow, International Food Policy and Research Institute

- Yuan Zhou, Head of Agricultural Policy and China Program, Syngenta Foundation for Sustainable Agriculture 